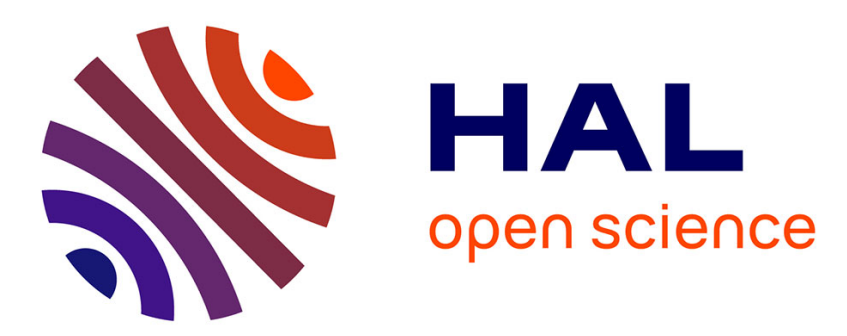

\title{
In vitro approach to the control of spermatogonia proliferation in the trout
}

Maurice Loir

\section{To cite this version:}

Maurice Loir. In vitro approach to the control of spermatogonia proliferation in the trout. Molecular and Cellular Endocrinology, 1994, 102, pp.141-150. 10.1016/0303-7207(94)90107-4 . hal-02713935

\section{HAL Id: hal-02713935 \\ https://hal.inrae.fr/hal-02713935}

Submitted on 1 Jun 2020

HAL is a multi-disciplinary open access archive for the deposit and dissemination of scientific research documents, whether they are published or not. The documents may come from teaching and research institutions in France or abroad, or from public or private research centers.
L'archive ouverte pluridisciplinaire HAL, est destinée au dépôt et à la diffusion de documents scientifiques de niveau recherche, publiés ou non, émanant des établissements d'enseignement et de recherche français ou étrangers, des laboratoires publics ou privés. 


\title{
In vitro approach to the control of spermatogonia proliferation in the trout
}

\author{
Maurice Loir* \\ Physiologie des Poissons, INRA, Campus de Beaulieu, 35042 Rennes, France
}

(Received 24 January 1994; accepted 7 March 1994)

\begin{abstract}
When spermatogonia and primary spermatocytes $(\mathrm{Go}+\mathrm{CI})$, uncontaminated by somatic testicular cells, were prepared from trout testes at various maturation stages and cultured alone, basal tritiated thymidine $\left({ }^{3} \mathrm{H}\right.$-Tdr) incorporation decreased throughout the reproductive cycle. It was unchanged by salmon gonadotropin (sGtH II), trout growth hormone (rhGH), testosterone, estradiol and $17 \alpha, 20 \beta$-dihydroprogesterone. Conversely, it was dose-dependently stimulated by rhIGF-I, with a mean $\mathrm{ED}_{50}$ of $5.2 \mathrm{ng} / \mathrm{ml}$ and a mean maximum stimulation of 3.2-fold above control. When Go $+\mathrm{CI}$ were cultured either in the presence of Sertoli cells or in Sertoli cell-conditioned medium (SCCM), basal ${ }^{3} \mathrm{H}$-Tdr incorporation was always decreased when the Sertoli cells were from spermatogenetic testes, but it was stimulated when they were from testes which were to resume spermatogenesis soon. Whatever the origin of the Sertoli cells, they always partly inhibited IGF-I stimulation. When present during either the co-cultures or the preparation of SCCM, sGtH II and rtGH had no effect when Sertoli cells were from spermatogenetic testes. In conclusion, IGF-I is a direct efficient stimulator of the proliferation of trout male germ cells, the effect of which is partly counteracted by Sertoli cells. sGtH II, rtGH and the 3 tested steroids are not directly active. While sGtH II has no Sertoli cell-mediated activity, further investigation is necessary to clarify whether the other tested molecules have such an activity.
\end{abstract}

Key words: (Trout); (Spermatogonia); (Sertoli cell); Insulin-like growth factor; Gonadotropin; Growth hormone; Steroid

\section{Introduction}

Spermatogenesis starts with the proliferation of spermatogonia. In mammals, initiation and maintenance of spermatogenesis is dependent on folliclestimulating hormone (FSH) secreted by the pituitary, and on androgens secreted by Leydig cells (Chemes et al., 1979; Bartlett et al., 1989). These hormones are assumed to exert only indirect actions on germ cells, the Sertoli cells being the only target. Their effect would be mediated by locally produced factors with a paracrine function. In vivo and in vitro studies have suggested that various testicular products could either inhibit or stimulate the proliferation of spermatogonia and their differentiation to primary spermatocytes (for review see Giordano et al., 1991; Jégou, 1993). However, only a few studies have demonstrated that pre-

\footnotetext{
* Fax: 99-28-50-20.
}

sumed active factors interact effectively, in vitro, with the cells present in the seminiferous tubules. This was the case only for IGFs (Söder et al., 1992), activin and TGF- $\beta_{1}$ (Mather et al., 1990; Hakovirta et al., 1993) which influence tritiated thymidine $\left({ }^{3} \mathrm{H}-\mathrm{Tdr}\right)$ uptake either in segments of rat seminiferous tubules or in rat spermatogonia co-cultured with Sertoli cells. In addition, activin could have a direct action on the spermatogonia as this factor specifically binds to these cells. On the contrary, although IGFs and TGF- $\beta_{1}$ are presumed to be paracrine factors produced by Sertoli cells, conclusive evidence of a direct interaction between these factors and germ cells is still lacking.

Our knowledge about the factors regulating germ cell proliferation in the fish testis is still more limited. In vivo investigations and in vitro studies using tissue culture systems have pointed out that mammalian (growth hormone, GH; human chorionic gonadotropin) or fish (gonadotropin II, GtH II) pituitary hormones, as well as androgens (testosterone) are able to induce 
spermatogonial multiplication in either intact (Khan et al., 1987) or hypophysectomized (Sundararaj et al., 1971; Pickford et al., 1972; Khan et al., 1987) or juvenile fish (Upadhyay, 1977; Magri et al., 1985), or in testicular fragments (Remacle, 1976; Cochran, 1992). In addition, it has been proposed that transformation of trout spermatogonia to spermatocytes is regulated through GtH control (Ruby et al., 1993). In selachian fish, studies have led to the hypothesis that androgens, estradiol and IGF-I could be involved in stem cell/ spermatogonial proliferation (Callard et al., 1989; Dubois and Callard, 1993). At the present time, it is unknown whether the effects of the hormones and factors potentially involved in the regulation of germ cell proliferation in fish are direct on these cells or mediated by factors produced in the testis.

Salmonids are seasonal breeders. Histological and physiological changes in the testis are a normal part of seasonal reproductive cycles and, from the onset of spermatogenesis to the regression phase, the events throughout the testis tend to be synchronized. In the trout, type A spermatogonia are permanent cells in the testis. For about six months, when the gonads are engaged in spermatogenesis (maturation stages II-VI), these cells proliferate together with the resulting type B spermatogonia (Billard, 1983). Later, during the spermiation phase (maturation stages VII-VIII) and the regression phase (maturation stage IX), only quiescent type A spermatogonia are present. We recently developed methods to separate trout testicular cell populations and to culture them (Loir and Sourdaine, 1994). In this study, we checked the usefulness of this cell separation and culturc model system to study interactions between mitotic trout germ and Sertoli cells (SC) and, secondly, to identify molecules that are able to influence in vitro DNA synthesis in male germ cells, either directly or through Sertoli cell mediation. GtH II, GH, IGF-I and three steroids have been considered.

\section{Materials and methods}

\subsection{Materials}

Collagenase A, Mitomycin C and hydroxyurea were from Boehringer Mannheim. Percoll was from Pharmacia. Ultroser $G(5 \times$ concentrated fetal calf serum substitute) was from IBF-Sepracor, Villeneuve-la-Garenne, France. Hexadecyltrimethylammonium bromide (HTAB) was from Kodak laboratory chemicals. Deoxyribonuclease (DNase), Poly-L-lysine, culture media, salmon protamine, tTestosterone, estradiol-17 $\beta$ and $17 \alpha, 20 \beta$-dihydroxy-4-pregnen-3-one (17,20-OH-P) were from Sigma Chemical. Suramin was from Bayer, Germany. [Methyl- ${ }^{3} \mathrm{H}$ ]thymidine $\left({ }^{3} \mathrm{H}-\mathrm{Tdr}\right.$; code TRK300, spec. act. $925 \mathrm{GBq} / \mathrm{mmol}$ ) and 5-bromo-2'-deoxyuridine (BrdU; cell proliferation kit II) were from Amersham. sGtH II (carbohydrate-rich maturational gonadotropin) was kindly donated by Dr. B. Breton, rtGH by Eurogentec and rhIGF-I by Ciba-Geigy.

\subsection{Preparation and culture of spermatogonia and primary spermatocytes}

Two- and three-year-old male rainbow trout (Oncorhynchus mykiss), kept in recycled freshwater at $12-15^{\circ} \mathrm{C}$ under natural photoperiod, were used. Fish were anesthetized with $3 \%$ phenoxyethanol, then killed by a blow to the head. All the following operations were carried out in sterile conditions at $12-13^{\circ} \mathrm{C}$. Two to 6 testes were removed from at least 2 males at the same maturation stage. Maturation stages were determined according to Billard and Escaffre (1975). Stages II and III correspond to early spermatogenesis; stages IV and V to mid-spermatogenesis, stages VI and VII to late spermatogenesis/beginning of spermiation; stage VIII to spermiation and stage IX to testis regression.

The methods used to prepare testis cell suspensions have been described in detail elsewhere (Loir and Sourdaine, 1994). In brief, testes were perfused with a $0.8 \mathrm{mg} / \mathrm{ml}$ collagenase solution in culture medium with $\mathrm{Mg}^{2+}$ but not $\mathrm{Ca}^{2+}$. They were cut into pieces, lightly shaken overnight in $\mathrm{L}-15$ medium plus $1 \% \mathrm{BSA}$ and $2 \%$ Ultroser $G$, then the cell suspension was filtered through a $150 \mu \mathrm{m}$ nylon filter. When each of both testes of males was submitted either to collagenase perfusion or to mechanical dissociation (Loir and Sourdaine, 1994), neither the basal incorporation of ${ }^{3} \mathrm{H}-\mathrm{Tdr}$ by germ cells nor the responsiveness of these cells to IGF-I differed significantly.

When present in the testicular cell suspension, most of the spermatozoa were removed by low-speed centrifugation in an isotonic Percoll solution (mean density: $1.065 \mathrm{~g} / \mathrm{ml}$; Loir, 1988; Loir and Sourdaine, 1994). The obtained floating cell layers were collected, diluted six times with L- 15 medium and cells were pelleted by centrifugation $(50 \times \mathrm{g}, 10 \mathrm{~min})$. Populations enriched in spermatogonia (Go) and primary spermatocytes (CI) from spermatogenetic testes were routinely prepared by centrifugal elutriation as described by Loir and Sourdaine (1994) and modified as follows. Two 150 $\mathrm{ml}$ fractions were collected at 13 instead of $12.3 \mathrm{ml} / \mathrm{min}$ then at 19 instead of $16.7 \mathrm{ml} / \mathrm{min}$. Cells present in these two fractions were pelleted, washed once by centrifugation $(50 \times \mathrm{g}, 10 \mathrm{~min})$, resuspended in L-15 medium plus $2 \%$ Ultroser $\mathrm{G}\left(20 \times 10^{6}\right.$ or less round cells $/ \mathrm{ml}$ ), then seeded in Nunc $80 \mathrm{~cm}^{2}$ culture flasks $(15 \mathrm{ml} /$ flask) and left overnight without shaking (preculture step).

Populations enriched in spermatogonia (Go) were prepared from spermiating and regressed testes by 
sedimentation at $1 \times g$ as described elsewhere (Loir and Sourdaine, 1994). Briefly, testis cells were resuspended in $20 \mathrm{ml} 0.2 \%$ BSA in L-15, then loaded onto a $550 \mathrm{ml}$ non-linear $0.5,2$ and $3.5 \%$ BSA gradient, in a "stepped" sedimentation chamber. Four hours later, a fraction corresponding to sedimentation velocities ranging from 4.6 to $9 \mathrm{~mm} / \mathrm{h}$ was collected. Cells were washed by centrifugation, then seeded in pre-culture a above.

Germ cells which had not adhered to plastic during the pre-culture step were collected, centrifuged $(50 \times g$, $5 \mathrm{~min}$ ), washed twice, then counted. Usually, fractions I and II were then pooled. Cells were suspended in 400 $\mu 1$ either L-15 medium or SC-conditioned medium (SCCM) diluted to 66 or $75 \%$ with fresh L-15 medium. Routinely, between 0.4 and $2.5 \times 10^{6}$ Go $+\mathrm{CI}$ were seeded per well in Nunc plastic 24 -well plates. These cell numbers were chosen after preliminary experiments which showed that in our cell culture and ${ }^{3} \mathrm{H}-\mathrm{Tdr}$ labelling conditions: (1) ${ }^{3} \mathrm{H}-\mathrm{Tdr}$ incorporation by $10^{3}$ $\mathrm{Go}+\mathrm{CI}$ was constant up to $2.5 \times 10^{6} \mathrm{Go}+\mathrm{CI} /$ well; (2) the half-maximum effective concentration $\left(\mathrm{ED}_{50}\right)$ for IGF-I was constant when at least $0.4 \times 10^{6} \mathrm{Go}+\mathrm{CI}$ and up to $3.3 \times 10^{6}$ Go $+\mathrm{CI}$ were seeded per well; (3) tritium autoabsorption did not vary up to $3 \times 10^{6} \mathrm{Go}+$ CI per well.

Two hours after seeding, molecules to be tested were added at various concentrations in quadruplicate wells. Routinely, cultures were kept for 3 days, under air, without shaking.

\subsection{Preparation and culture of Sertoli cells}

The floating cell suspension obtained after removal of spermatozoa was adjusted with Percoll to a mean density of $1.039 \mathrm{~g} / \mathrm{ml}$ and SC were prepared according to Loir and Sourdaine (1994). The obtained SC suspension was washed by 2-4 centrifugations at $50 \times g$ for 3 min to remove most of the contaminating germ cells not included in SC, then resuspended in $\mathrm{L}-15$ medium plus $2 \%$ Ultroser $\mathrm{G}$ and seeded in culture (between 1 and $7 \times 10^{6} \mathrm{SC}$ per $\mathrm{cm}^{2}$ ). After 6-20 h, the medium was removed and the cell layer was washed. In the case of co-cultures in contact, either a $\mathrm{Go}+\mathrm{CI}$ suspension was added onto the SC layer or not ("SC layer" samples). In the case of co-cultures without cellular con-
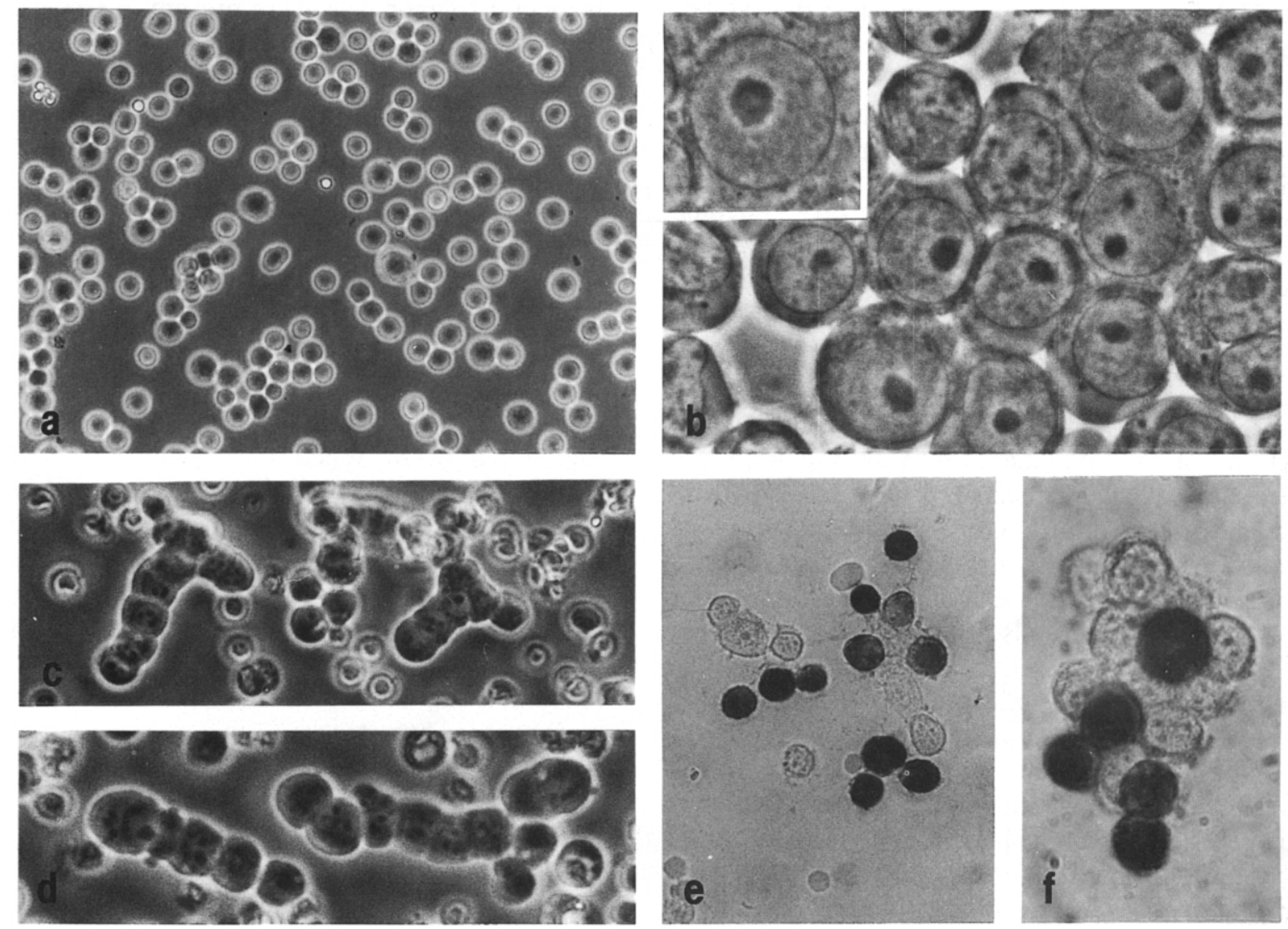

Fig. 1. Spermatogonia plus primary spermatocytes populations prepared from trout testes at various maturation stages. (a) Stage IV; cell population before seeding; $\times 340$. (b) Stage VIII; 8 days in culture, B spermatogonia; insert: one A spermatogonium; $\times 1$ 800. (c,d) Stage III; 3 days in culture in the presence of $100 \mathrm{ng} / \mathrm{ml}$ IGF-I; clusters and chains of spermatogonia mixed with damaged spermatocytes and spermatids; (c) $\times 500$; (d) $\times 650$. (e,f) Stage V; bromo-2'-deoxyuridine labelling; cells were cultured either on glass coverslips coated with poly-L-lysine (e) or in suspension ( $f$ ), for 3 days in the presence of $100 \mathrm{ng} / \mathrm{ml}$ IGF-I, then fixed and treated for BrdU labelling; (e) $\times 640$; (f) $\times 1100$. 
tact, Go $+\mathrm{CI}$ were added in chamber inserts (Costar's transwells, ref. 3 413) above the SC layer. To prepare SC-conditioned media (SCCM), only fresh L-15 medium was added. SCCM were collected either one or two days later, centrifuged at $400 \times g$ for $10 \mathrm{~min}$ and either used immediately or stored at $-20^{\circ} \mathrm{C}$. Control media to SCCM were prepared by processing simultaneously and identically, culture medium without cells.

\section{4. $\left[{ }^{3} H\right]$ Thymidine incorporation}

Eight $\mu \mathrm{Ci}{ }^{3} \mathrm{H}$-Tdr was added per $\mathrm{ml}(3.2 \mu \mathrm{Ci} /$ well $)$ for the last $24 \mathrm{~h}$ in culture. The medium was then replaced by fresh medium containing thymidine $(\times 2000)$ and the cells cultured further for $4 \mathrm{~h}$. The nuclei were prepared with $0.4 \%$ HTAB plus $1 \mathrm{mM}$ $\mathrm{CaCl}_{2}$. They were counted, then collected on GF/C Whatman filters, washed with 5\% perchloric acid followed by ethanol, and dried. The incorporated radioactivity (cpm) was counted in the presence of Insta-Fluor in a Packard Tricarb counter. It was then ascribed to $10^{3} \mathrm{Go}+\mathrm{CI}$ nuclei retrieved in the wells. Preliminary experiments have indicated that, in our cell culture conditions, up to $3 \times 10^{6} \mathrm{Go}+\mathrm{Cl} /$ well, the amount of added ${ }^{3} \mathrm{H}$-Tdr was not limiting, even when the ${ }^{3} \mathrm{H}$-Tdr incorporation was stimulated 4-fold above control by IGF-I.

When $\mathrm{Go}+\mathrm{CI}$ were cultured in the presence of $1.25 \mu \mathrm{g} / \mathrm{ml}$ mitomycin plus $0.4 \mathrm{mg} / \mathrm{ml}$ hydroxyurea, ${ }^{3} \mathrm{H}$-Tdr incorporation varied between 4 and $8 \%$ of that measured in basal conditions. After BrdU labelling, some scarce large Go escaped the blocking effect of mitomycin plus hydroxyurea.

\subsection{5-Bromo-2'-deoxyuridine labelling}

BrdU labelling was carried out according to the instructions of the manufacturer, with the following modification: cells were incubated with $15 \mu \mathrm{M}$ BrdU for the last $24 \mathrm{~h}$ in culture. Go $+\mathrm{CI}$ suspensions to be labelled were cultured either in suspension or on glass coverslips coated with poly-L-lysine. Some samples of total testicular cells were also BrdU-labelled.

\subsection{Counting and cell identification}

Cells and nuclei were counted using a hemocytometer on a phase contrast microscope. Germ cells and somatic cells, and their nuclei, were identified according to criteria given elsewhere (Loir, 1988, 1989). Testicular macrophages were also identified by an in vitro test (phagocytosis of carbon particles).

According to Billard (1983), spermatogonia $A\left(G_{A}\right)$ are found in situ either isolated or in groups of 2 . They are the largest male germ cells (mean nuclear diameter: about $9 \mu \mathrm{m}$; cellular diameter: $10-12 \mu \mathrm{m}$ ). Sper- matogonia $B\left(G_{B}\right)$, grouped in situ in cysts, are smaller than $G_{A}$ (Fig. 1b) and their size decreases progressively when more division occurs (cellular and nuclear diameters: respectively $6.5-9$ and 5-8 $\mu \mathrm{m}$ ). The size of preleptotene and leptotene spermatocytes is similar to that of the smallest $G_{B}$. The other primary spermatocytes are somewhat larger. Routinely, when cells or nuclei were counted, it was not possible to distinguish $G_{B}$ and primary spermatocytes.

\subsection{Miscellaneous techniques}

A certain number of aliquots of $\mathrm{Go}+\mathrm{CI}$ populations were processed for electron microscopy after 3-8 days in culture according to Loir (1989). Data were analyzed using the Mann-Whitney $U$-test.

\section{Results}

\subsection{Preparation and cellular composition of $\mathrm{Go}+\mathrm{CI}$ populations}

After elutriation and sedimentation at $1 \times g$, some testicular somatic cells were present in $\mathrm{Go}+\mathrm{CI}$ or Go fractions. Pre-culture for at least $6 \mathrm{~h}$ in the presence of $2 \%$ Ultroser $\mathrm{G}$ allowed all these cells to adhere to plastic. Controls of the absence of (1) GtH II-stimulated conversion of $17 \alpha$-hydroxyprogesterone to androgens (Vizziano, 1993) and (2) of somatic cells in the culture plates after 3 days in culture, has confirmed that these cells were all removed during the pre-culture step. Fractions I and II obtained after elutriation contained mainly Go and CI. They contained also secondary spermatocyte and spermatid symplasts (multinucleated cells; Loir, 1989) with 2-4 nuclei. The fraction obtained after sedimentation at $1 \times g$ contained mainly Go. When present in the testes, spermatozoa were not all removed by centrifugation in Percoll and some ( $\leq 10 \%$ of the total cell number) contaminated the fractions. Some erythrocytes (less than $1 \%$ of the total cell number) were also usually present. So, in the populations seeded in culture, $74 \pm 13 \%(n=11)$ of the cells were Go and CI (Fig. 1a,b). Most of the contaminating cells were round spermatids and secondary spermatocytes.

\subsection{Preparation and composition of Sertoli cell preparations}

Because very low numbers of SC were obtained from testes in early spermatogenesis, SC were prepared only from testes at other maturation stages. A mean of $2-5 \times 10^{6} \mathrm{SC}$ (12 exp.) were obtained per $\mathrm{g}$ of testis. As already observed (Loir, 1989), the dissociated $\mathrm{SC}$ always contained Go (one for 1-4 SC; mostly $\mathrm{G}_{\mathrm{A}}$ 
and first generations of $\mathrm{G}_{\mathrm{B}}$ ) enclosed in their cytoplasm. Occasionally, some scarce interstitial cells were present. Contamination by secondary spermatocytes, spermatids and spermatozoa varied with the maturation stage, but was usually low.

\subsection{Cellular changes in culture}

When Go + CI were cultured alone for 3 days, paired Go and small clusters or small straight or branched chains, composed of 3-8 Go (Fig. 1c,d) were often observed, especially when $100 \mathrm{ng} / \mathrm{ml} \mathrm{IGF-I} \mathrm{was}$ present. During culture, numerous CI rapidly acquired an abnormal refringence. After 3 days, most of the large $\mathrm{CI}$, especially the pachytene ones easily identified by the presence of synaptonemal complexes, had either a shrunk, condensed, electron-opaque nucleus or a nucleus whose chromatin was condensed and located peripherally. After preparation with HTAB solution, we recovered $76.5 \pm 7.7 \%$ (12 exp.) of the nuclei of seeded $\mathrm{Go}+\mathrm{CI}$, cultured alone in basal conditions for 3 days. However, the number of retrieved nuclei was usually about two times as high compared to the unstimulated wells when a 3- to 4-fold stimulation of ${ }^{3} \mathrm{H}$ - Tdr incorporation was induced by $100-250 \mathrm{ng} / \mathrm{ml}$ of IGF-I. When $\mathrm{Go}+\mathrm{CI}$ were co-cultured with SC, in basal conditions, either in contact or in chamber inserts (no significant difference) instead of being cultured alone, the viability of the germ cells was improved: $19 \pm 3.4 \%$ (7 exp.) more nuclei were retrieved.

\subsection{Proliferation of Go $+\mathrm{CI}$ cultured alone in basal conditions}

In basal conditions (and also in stimulated conditions), the BrdU-labelled cells were identified as being

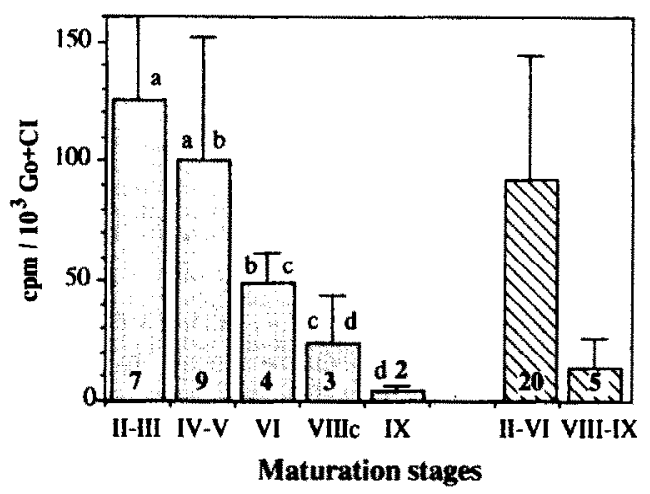

Fig. 2. Basal incorporation of $\left({ }^{3} \mathrm{H}\right)$ thymidine by spermatogonia plus primary spermatocytes (Go $+\mathrm{Cl}$ ), as a function of the maturation stage of the testes. Stages II to VI: spermatogenesis; stages VIII to IX: spermiation and regression phase. Go $+\mathrm{Cl}$ were cultured for 3 days. $\left({ }^{3} \mathrm{H}\right)$ thymidine $(8 \mu \mathrm{Ci} / \mathrm{ml})$ was present for the last day. Mean of 4 wells $\pm S D$. Squares with the same small letter are not significantly different. The numbers of experiments are indicated at the bottom of the squares.

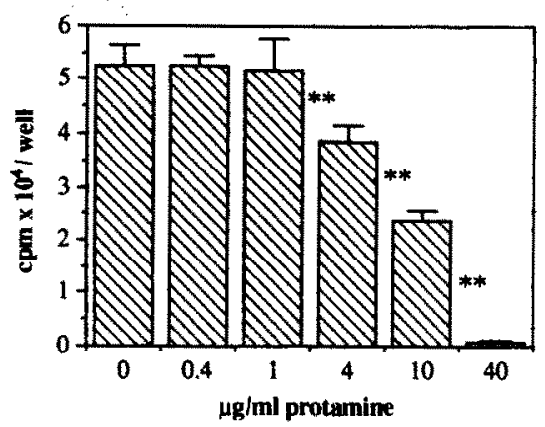

Fig. 3. Effect of increasing concentrations of protamine on basal incorporation of $\left[{ }^{3} \mathrm{H}\right]$ thymidine by spermatogonia plus spermatocytes $(\mathrm{Go}+\mathrm{Cl})$ prepared from testes in late spermatogenesis. $0.45 \times 10^{6}$ Go $+\mathrm{Cl}$ were seeded per well, then cultured and labelled as in Fig. 3. Mean of 4 wells $\pm S D$. ${ }^{* *} P<0.015$.

Go and CI (Fig. 2). When total testicular cells were cultured on coverslips and BrdU-labelled in the same conditions as Go $+\mathrm{CI}$ populations, only $0.9 \%$ of the labelled cells were somatic cells.

Basal incorporation of ${ }^{3} \mathrm{H}-\mathrm{Tdr}$ by Go or $\mathrm{Go}+\mathrm{CI}$ $\left(\mathrm{cpm} / 10^{3} \mathrm{Go}+\mathrm{CI}\right)$ from testes at the various maturation stages was found to decrease throughout the reproductive cycle (Fig. 3 ). In the presence of protamine (Fig. 4), the basal ${ }^{3} \mathrm{H}-\mathrm{Tdr}$ incorporation remained unchanged for up to $1 \mu \mathrm{g} / \mathrm{ml}$ protamine. Starting from 4 $\mu \mathrm{g} / \mathrm{ml}$, it decreased in a dose-dependent manner.

While $0.35 \mathrm{mM}$ suramin present during 3 days was somewhat toxic for the $\mathrm{Go}+\mathrm{Cl}, 0.07 \mathrm{mM}$ was not. This suramin concentration slightly but significantly stimulated (1.15- to 1.37-fold, 4 exp.) the basal ${ }^{3} \mathrm{H}$-Tdr incorporation by $\mathrm{Go}+\mathrm{CI}$ (Fig. 5).

\subsection{Proliferation of Go + CI cultured alone: effects of $G t H, G H, I G F-I$ and steroids}

${ }^{3} \mathrm{H}$-Tdr incorporation by $\mathrm{Go}+\mathrm{Cl}$ from testes at various maturation stages was not significantly changed

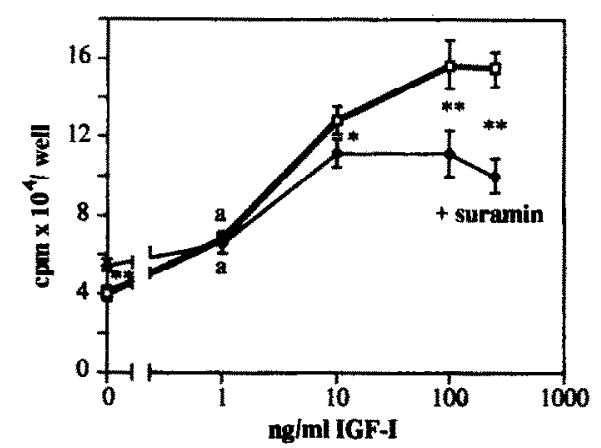

Fig. 4. Effect of increasing concentrations of rhIGF-I on $\left[{ }^{3} \mathrm{H}\right]$ thymidine incorporation by spermatogonia plus primary spermatocytes $(\mathrm{Go}+\mathrm{Cl})$ prepared from testes in mid-spermatogenesis then cultured for 3 days in the presence or not of $0.07 \mathrm{mM}$ suramin and labelled as in Fig. 3. $1.4 \times 10^{6} \mathrm{Go}+\mathrm{Cl}$ were seeded per well. Mean of 4 wells \pm SD. ${ }^{*} P<0.03 ;{ }^{* *} P<0.015$. a: minimal stimulation significant with respect to basal $\left({ }^{3} \mathrm{H}\right)$ thymidine incorporation. 
in the presence of $\mathrm{sGtH}$ II $(50-500 \mathrm{ng} / \mathrm{ml} ; 6$ exp.), rtGH (20-500 ng/ml; 6 exp.), 17,20-OH-P (5-300 $\mathrm{ng} / \mathrm{ml} ; 5 \mathrm{exp}$.), testosterone (5-100 $\mathrm{ng} / \mathrm{ml} ; 5 \mathrm{exp}$.) and estradiol ( $2-50 \mathrm{ng} / \mathrm{ml} ; 4$ exp.).

${ }^{3} \mathrm{H}$-Tdr incorporation by $\mathrm{Go}+\mathrm{CI}$ from testes at various maturation stages was increased in a dose-dependent manner by rhIGF-I (Fig. 5), with a mean $\mathrm{ED}_{50}$ of $5.2 \pm 3.3 \mathrm{ng} / \mathrm{ml}(7 \mathrm{exp}$.) and a mean maximum stimulation equal to 3.2 -fold ( $\pm 0.9,7$ exp.) above control. The effect of protamine on the response of $\mathrm{Go}+$ CI to IGF-I was identical to that observed on basal ${ }^{3} \mathrm{H}$-Tdr incorporation (data not shown). The stimulation by $1-100 \mathrm{ng} / \mathrm{ml}$ of IGF-I was inhibited $55-72 \%$ in the presence of $0.07 \mathrm{mM}$ suramin ( 2 exp.; Fig. 5 ).

\subsection{Influence of Sertoli cells on basal Go $+C I$ proliferation}

The ${ }^{3} \mathrm{H}$-Tdr incorporation by $10^{3}$ Go included in SC ("SC layer" samples) did not decrease significantly throughout the spermatogenetic phase. It was equal to $73 \pm 31$ (2 exp.), $65 \pm 35$ (5 exp.) and $59 \pm 25$ (3 exp.) cpm $/ 10^{3}$ Go from early spermatogenetic, mid-spermatogenetic and late spermatogenetic testes respectively. At the end of spermiation (stage VIIIc) it was much lower: $5 \pm 0.2 \mathrm{cpm} / 10^{3}$ Go ( 2 exp.).

Because after 3 days in co-culture, the added Go + $\mathrm{CI}$ could not be collected separately from the SC layer, ${ }^{3} \mathrm{H}$-Tdr incorporation by these added cells was determined by deducting that obtained for the Go included in the SC ("SC layer" samples) from that obtained for the whole co-culture. In this case, it appeared that the SC (from mid- and late spermatogenetic testes; no experiment with SC from other testes) always induced a conspicuous reduction of the ${ }^{3} \mathrm{H}$-Tdr incorporation by Go + CI (Table 1$)$. Suramin $(0.07 \mathrm{mM})$ partly antagonized this reduction as it induced a 1.34 - to 1.83 -fold (3 exp.) stimulation of ${ }^{3} \mathrm{H}$-Tdr incorporation by $\mathrm{Go}+\mathrm{CI}$ in co-cultures. When $\mathrm{Go}+\mathrm{CI}$ and $\mathrm{SC}$ were co-cultured

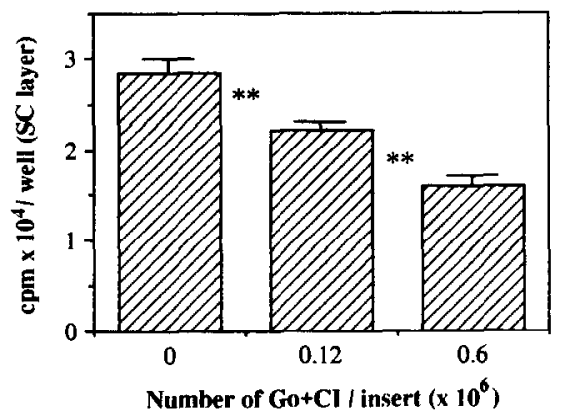

Fig. 5. Influence of variable numbers of spermatogonia plus spermatocytes $(\mathrm{Go}+\mathrm{CI})$ seeded in chamber inserts, on basal $\left({ }^{3} \mathrm{H}\right)$ thymidine incorporation by spermatogonia $\left(0.41 \times 10^{6} \mathrm{Go}\right)$ included in Sertoli cell layers $\left(0.43 \times 10^{6} \mathrm{SC}\right)$ cultured under the inserts. $\mathrm{Go}+\mathrm{CI}$ and $\mathrm{SC}$ were prepared from testes in late spermatogenesis, then cultured and labelled as in Fig. 3. Mean of 4 wells \pm SD. ${ }^{*} P<0.03 ;{ }^{* *} P<$ 0.015 .
Table 1

Influence of Sertoli cells (SC) from testes at various maturation stages on basal $\left({ }^{3} \mathrm{H}\right)$ thymidine incorporation $\left({ }^{3} \mathrm{H}-\mathrm{Tdr}\right)$ by spermatogonia plus primary spermatocytes $(\mathrm{Go}+\mathrm{CI})$ from spermatogenetic testes $\mathrm{Go}+\mathrm{CI}$ were cultured either alone $\left({ }^{3} \mathrm{H}-\mathrm{Tdr}\right.$ was then arbitrarily fixed at $100 \mathrm{cpm} / 10^{3} \mathrm{Go}+\mathrm{CI}$ ) or in the presence of $\mathrm{SC}$ (in contact or in inserts) or in SC-conditioned medium (SCCM). Values with a different letter differ significantly. Mean $\pm \mathrm{SD}$

\begin{tabular}{lll}
\hline & $\begin{array}{l}\text { Origin } \\
\text { of SC }\end{array}$ & $\begin{array}{l}\mathrm{cpm}^{3} \mathrm{H}-\mathrm{Tdr} \\
/ 10^{3} \mathrm{Go}+\mathrm{CI}\end{array}$ \\
\hline $\begin{array}{l}\text { Go }+\mathrm{CI} \\
\text { alone }\end{array}$ & $\begin{array}{l}(100) \\
(\mathrm{n}=12) \mathrm{a}\end{array}$ \\
$\begin{array}{l}\text { Go }+\mathrm{CI} \\
\text { laid on SC }\end{array}$ & $\begin{array}{l}\text { Spermato- } \\
\text { genesis }\end{array}$ & $\begin{array}{l}39.2 \pm 15.8 \\
(\mathrm{n}=10) \mathrm{b}\end{array}$ \\
$\begin{array}{l}\text { Go }+\mathrm{CI} \\
\text { in inserts }\end{array}$ & $\begin{array}{l}\text { Spermato- } \\
\text { genesis }\end{array}$ & $\begin{array}{l}55.3 \pm 13.2 \\
(\mathrm{n}=7) \mathrm{c}\end{array}$ \\
$\begin{array}{l}\text { Go }+\mathrm{CI} \\
\text { in SCCM }\end{array}$ & $\begin{array}{l}\text { Spermato- } \\
\text { genesis }\end{array}$ & $65.2 \pm 13.3$ \\
Go $+\mathrm{CI}$ & end of & 100,143 \\
in SCCM & spermiation & $(\mathrm{n}=2)$ \\
Go+CI & regression & 230,295 \\
in SCCM & phase & $(\mathrm{n}=2)$ \\
\hline
\end{tabular}

in the bicameral system, the basal ${ }^{3} \mathrm{H}-\mathrm{Tdr}$ incorporation was decreased, but only about half (Table 1). The decrease was only slightly influenced by the relative numbers of Go $+\mathrm{CI}$ and of SC (the ratio Go $+\mathrm{CI} / \mathrm{SC}$ varied between 0.45 and 2.3 in the 7 above-mentioned experiments). In such co-cultures, ${ }^{3} \mathrm{H}-\mathrm{Tdr}$ incorporation by the Go included in the SC layer was decreased by the addition of Go $+\mathrm{CI}$ in the inserts, this effect being correlated to the number of added germ cells (Fig. 6). When Go + CI and SC from spermatogenetic testes were cultured separately and co-cultured, in contact and in the bicameral system ( 3 exp.), the total ${ }^{3} \mathrm{H}$-Tdr incorporation by the Go included in SC plus the added $\mathrm{Go}+\mathrm{CI}$ was more inhibited when the 2 populations were in contact than when they were not (Fig. 7).

When spermatogenetic Go $+\mathrm{CI}$ were cultured in SCCM, prepared from spermatogenetic testes, basal ${ }^{3} \mathrm{H}-\mathrm{Tdr}$ incorporation was decreased to $65.2 \pm 13.3 \%$ (12 exp.) as compared to that of the same cells cultured in control media (Table 1). Conversely, the basal ${ }^{3} \mathrm{H}$ Tdr incorporation by mid- and late spermatogenetic $\mathrm{Go}+\mathrm{CI}$ was either unchanged or stimulated (Table 1) when SCCM were prepared from testes either at the end of spermiation or regressing.

\subsection{Sertoli cells-germ cells co-culture: effects of IGF-I}

Co-culture of $\mathrm{Go}+\mathrm{CI}$ with $\mathrm{SC}$, as well as inclusion of Go in SC, always induced a shift of the dose-response curve to IGF-I towards higher concentrations, resulting in higher $\mathrm{ED}_{50}$ (Table 2), in nearly complete inhibition of the stimulation induced by $1 \mathrm{ng} / \mathrm{ml} \mathrm{IGF-I}$ and in partial inhibition of those obtained with 10 and 


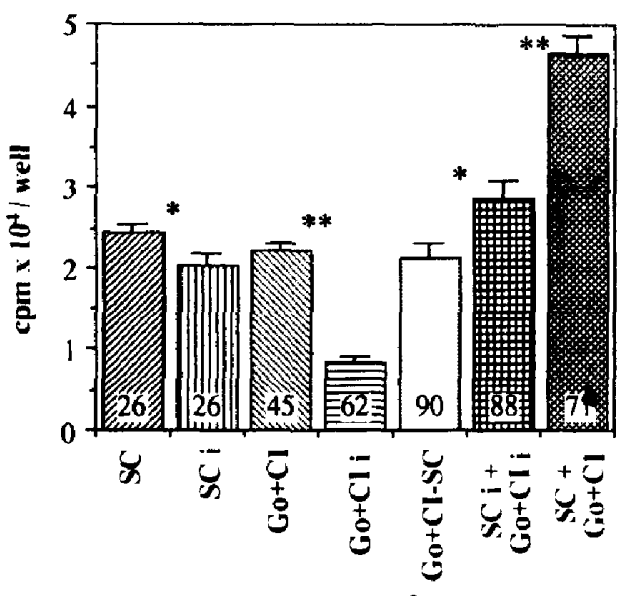

Fig. 6. Influence of co-culture on basal $\left({ }^{3} \mathrm{H}\right)$ thymidine incorporation by spermatogonia plus primary spermatocytes $(\mathrm{Go}+\mathrm{Cl})$ and by Go included in Sertoli cells, prepared from testes in late spermatogenesis, then cultured and labelled as in Fig. 3. Sertoli cell layers (SC) and $\mathrm{Go}+\mathrm{CI}$ were either cultured alone or separated by chamber inserts ( $\mathrm{SC} \mathrm{i}, \mathrm{Go}+\mathrm{CI}$ i) or in contact $(\mathrm{Go}+\mathrm{CI}-\mathrm{SC})$. The total $\left({ }^{3} \mathrm{H}\right)$ thymidine incorporation was lower when the cells were in contact than when they were separated by inserts $(\mathrm{SC} \mathrm{i}+\mathrm{Go}+\mathrm{CI} \mathrm{i})$ and about twice lower than when they were cultured alone $(\mathrm{SC}+\mathrm{Go}+\mathrm{CI})$. Numbers at the bottom of the squares: number $\left(\times 10^{5}\right)$ of retrieved Go or Go + CI. Mean of 4 wells $\pm \mathrm{SD} .{ }^{*} P<0.03{ }^{* *} P<0.015$.

$100 \mathrm{ng} / \mathrm{ml}$ IGF-I (Table 2). These effects werc observed for all the maturation stages of testes used to prepare SC. When 3 different concentrations of the same SC population were cultured with increasing concentrations of IGF-I, the stimulating effect of 1 and 10 $\mathrm{ng} / \mathrm{ml}$ of IGF-I on the ${ }^{3} \mathrm{H}$-Tdr incorporation by the included Go, decreased when the total number of cells increased (Fig. 8).

The culture of Go $+\mathrm{CI}$ in SCCM induced similar effects (Table 2). However, although the $\mathrm{ED}_{50}$ was increased, it did not significantly differ from that measured for the $\mathrm{Go}+\mathrm{CI}$ cultured alone. The inhibition of

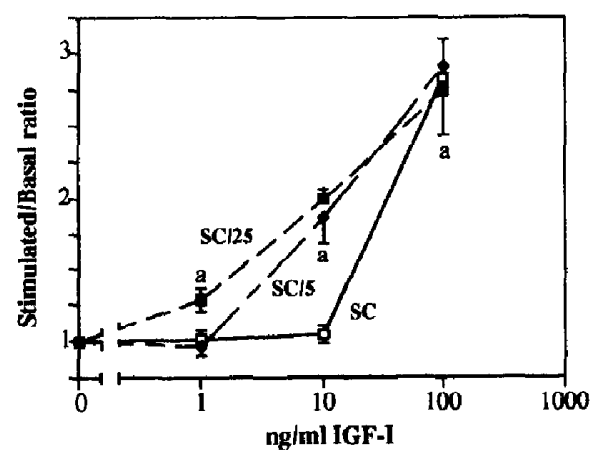

Fig. 7. Effect of increasing concentrations of rhIGF-I on $\left({ }^{3} \mathrm{H}\right)$ thymidine incorporation by spermatogonia (Go) included in Sertoli cells prepared from testes in late spermatogenesis, when 3 (SC), 0.6 $(\mathrm{SC} / 5)$ and $0.12(\mathrm{SC} / 25) \times 10^{6}$ Go included in about the same number of Sertoli cells, were seeded in culture and labelled as in Fig. 3. Results are expressed as the stimulated/basal ratio. Mean of 4 wells \pm SD. a: minimal stimulation significant with respect to basal $\left[{ }^{3} \mathrm{H}\right]$ thymidine incorporation.
Table 2

Influence of Sertoli cells on the IGF-I-induced stimulation of $\left({ }^{3} \mathrm{H}\right)$ thymidine incorporation by spermatogonia plus primary spermatocytes $(\mathrm{Go}+\mathrm{CI})$ or by spermatogonia $(\mathrm{Go})$ included in Sertoli cells (SC) $\mathrm{Go}+\mathrm{Cl}$ were cultured either alone or in contact with $\mathrm{SC}$ or in SC-conditioned medium (SCCM). Values in a same column, with a different letter differ significantly. Mean \pm SD

\begin{tabular}{lllll}
\hline & $\begin{array}{l}E_{50} \\
(\mathrm{ng} / \mathrm{ml})\end{array}$ & \multicolumn{3}{l}{$\begin{array}{l}\text { Percent inhibition } \\
\text { of the stimulation by IFG-I }\end{array}$} \\
\cline { 3 - 5 } & & $1 \mathrm{ng} / \mathrm{ml}$ & $10 \mathrm{ng} / \mathrm{ml}$ & $100 \mathrm{ng} / \mathrm{ml}$ \\
\hline $\begin{array}{l}\text { Go + CI } \\
\text { alone }\end{array}$ & $\begin{array}{l}5.9 \pm 3.7 \\
(\mathrm{n}=4) \mathrm{a}\end{array}$ & & & \\
$\begin{array}{l}\text { Go + CI } \\
\text { laid on SC }\end{array}$ & $\begin{array}{l}40.7 \pm 21.6 \\
(\mathrm{n}=4) \mathrm{b}\end{array}$ & $\begin{array}{l}97.5 \pm 5.0 \\
(\mathrm{n}-4) \mathrm{c}\end{array}$ & $\begin{array}{l}72.7 \pm 22.5 \\
(\mathrm{n}=4) \mathrm{e}\end{array}$ & $\begin{array}{l}32.1 \pm 15.6 \\
(\mathrm{n}=8) \mathrm{f}\end{array}$ \\
$\begin{array}{l}\text { Go included } \\
\text { in SC }\end{array}$ & $\begin{array}{l}46.5 \pm 27.8 \\
(\mathrm{n}=4) \mathrm{b}\end{array}$ & $\begin{array}{l}98.5 \pm 3.0 \\
(\mathrm{n}=4) \mathrm{c}\end{array}$ & $\begin{array}{l}63.0 \pm 32.0 \\
(\mathrm{n}=4) \mathrm{e}\end{array}$ & $\begin{array}{l}31.0 \pm 24.5 \\
(\mathrm{n}=4) \mathrm{f}\end{array}$ \\
$\begin{array}{l}\text { Go+CI } \\
\text { in SCCM }\end{array}$ & $\begin{array}{l}12.2 \pm 9.5 \\
(\mathrm{n}=6) \mathrm{a}\end{array}$ & $\begin{array}{l}72.1 \pm 13.0 \\
(\mathrm{n}=7) \mathrm{d}\end{array}$ & $\begin{array}{l}50.0 \pm 19.0 \\
(\mathrm{n}=12) \mathrm{e}\end{array}$ & $\begin{array}{l}34.8 \pm 20.0 \\
(\mathrm{n}=7) \mathrm{f}\end{array}$ \\
\hline
\end{tabular}

the stimulation by $1 \mathrm{ng} / \mathrm{ml}$ IGF-I was significantly lower than inhibition observed in the case of co-cultured Go + CI and of included Go.

\subsection{Sertoli cells germ cells co-culture: effects of GtH and GH}

The presence of GtH II (400-500 ng/ml; 5 exp.) did not change the ${ }^{3} \mathrm{H}$-Tdr incorporation by co-cultured $\mathrm{Go}+\mathrm{CI}$. When $\mathrm{rtGH}(200-500 \mathrm{ng} / \mathrm{ml} ; 6$ exp.) was present during co-cultures of spermatogenetic cells, or during the preparation of SCCM from spermatogenetic testes ( 3 exp.), the basal ${ }^{3} \mathrm{H}$-Tdr incorporation by Go + CI (in co-culture or in SCCM) was not significantly changed. However, when SCCM were prepared in the presence of $\mathrm{rtGH}$, from testes either at the end of spermiation or regressing, the stimulation of the basal ${ }^{3} \mathrm{H}$-Tdr incorporation by spermatogenetic $\mathrm{Go}+\mathrm{CI}$ was $10-40 \%$ inhibited in 2 experiments, while it was unchanged in a third one.

\section{Discussion}

Separation of trout testicular cells, by elutriation or sedimentation at $1 \times g$, followed by a pre-culture step produces mitotic germ cell populations devoid of somatic cells, which in any way, in concordance with previous data (Loir, 1989, 1990), had no significant proliferative activity during the three first days in culture. The germ cell populations contained mostly spermatogonia and spermatocytes. They contained also, in most cases, variable amounts of secondary spermatocytes, spermatids and spermatozoa. As these cells do not synthesize DNA, they do not interfere directly with the measurements of the ${ }^{3} \mathrm{H}$-Tdr incorporation by Go + CI. However, it is unknown whether these cells 
could have a paracrine effect on $\mathrm{Go}+\mathrm{CI}$, although no such direct interaction between germ cells has been demonstrated in mammals. It has been proposed (Tres et al., 1986; Hansson et al., 1989; Dombrowicz et al., 1992) that in rat testis, CI and perhaps Go, but not secondary spermatocytes and spermatids, could produce IGF-I. Co-cultures of trout male germ cells in the presence of IGFBP-3 (data not shown) suggest that these cells do not secrete IGF-I. While two studies (Tres et al., 1986; Vanelli et al., 1988) suggest that IGF-I receptors are present in CI, none support the presence of such receptors in spermatids and spermatozoa. IGF-I receptor immunoreactivity has been demonstrated in secondary spermatocytes only in human testis (Vanelli et al., 1988). If this is true also for trout secondary spermatocytes, it seems unlikely that these cells could act as mediators of the observed effects of IGF-I on Go + CI, as, in situ, they are absent at the time of initial Go proliferation.

Protamine is able to inhibit cell proliferation induced by some growth factors (Neufeld and Gospodarowicz, 1987). Although disintegration of contaminating spermatozoa during culture was not apparent, we have tested the possible effect of released protamine. A concentration of $1 \mu \mathrm{g} / \mathrm{ml}$, which is the maximum concentration having no effect on basal and IGF-stimulated ${ }^{3} \mathrm{H}$-Tdr incorporation, would correspond to $0.43 \times 10^{6}$ lysed spermatozoa per ml (Johnson et al., 1987). As the most contaminated cultures contained about $0.25 \times 10^{6}$ spermatozoa per $\mathrm{ml}$, we may exclude an interfering effect of damaged spermatozoa.

Data obtained with BrdU labelling on one hand and in the presence of mitomycin + hydroxyurea on the other, demonstrate that ${ }^{3} \mathrm{H}-\mathrm{Tdr}$ incorporation represents true DNA synthesis, i.e. the proliferative activity of the mitotic germ cells. This was confirmed by the increased number of nuclei retieved at the end of culture in the presence of $100-250 \mathrm{ng} / \mathrm{ml}$ IGF-I. Clusters of Go which were observed in cultures, likely result from this activity. The fact that at the end of cultures carried out without an efficient stimulator, less $\mathrm{Go}+\mathrm{CI}$ nuclei were retrieved than $\mathrm{Go}+\mathrm{CI}$ cells were seeded, is not in disagreement with the occurrence of germ cell proliferation, but is to be ascribed to the previously observed low viability of spermatocytes (4565\% after 2 days; Loir, 1989). In this study, confirmation of the occurrence of degenerative changes was provided by the evolution, during culture, of the ultrastructure of spermatocytes and of their nuclei.

A quantitative analysis of trout spermatogenesis $(\mathrm{Bi}-$ llard, 1983) establishes that both $G_{A}$ and $G_{B}$ divide actively during the spermatogenetic phase, while later, the present $G_{A}$ are quiescent. The changes of the in vitro proliferative activity of the $\mathrm{Go}+\mathrm{CI}$ cultured alone are in agreement with the in vivo situation. However, the origin of these in vitro changes addresses a question. Does the in vitro activity pattern either reflect an endogenous rhythm, possibly controlled by autocrine / intracrine regulations, or does it result from the persistence of some stimulatory and/or inhibitory controls undergone in situ by the mitotic germ cells ? No answer is available at the present time. We only know that $0.07 \mathrm{mM}$ suramin slightly enhances the basal proliferation rate of spermatogenetic Go $+\mathrm{CI}$. Because this polyanionic drug inhibits growth factor-receptor interactions (Czernin et al., 1993), its effect suggests that some inhibitory growth factor would modulate the autonomous proliferation of $\mathrm{Go}+\mathrm{CI}$.

Salmon GtH-II, rt-GH and the 3 tested steroids were unable to influence the proliferation of mitotic germ cells while IGF-I was able. Although the receptors for these various molecules could be differentially affected by in vitro processing, it has been shown previously that in our conditions, receptors to sGtH-II and to sGH were maintained for at least 4 days on total testicular cells (Le Gac et al., 1992). Thus, it can be assumed that these hormones do not act on mitotic trout germ cells, although we cannot exclude that they could act at some specific, presently unidentified, stage. According to Schulz et al. (1988), trout spermatogonia are not GtH-II immunoreactive.

Our results show for the first time in a vertebrate that IGF-I is a direct efficient stimulator of the proliferation of mitotic male germ cells. At the present time, only indirect stimulation mediated via Sertoli cells has been demonstrated in the rat (Söder et al., 1992) and in dogfish (Dubois and Callard, 1993). Until now, IGFI-immunoreactivity has never been detected in rat spermatogonia, while it was observed in spermatocytes (Tres et al., 1986; Hansson et al., 1989; Dombrowicz et al., 1992). Although IGF-I mRNA was detected in trout testis (Le Gac and Loir, 1993), the sites of synthesis are not known and the origin of the IGF-I involved in the control of germ cell activity remains to be determined.

Interactions, mediated via Sertoli cells, between successive generations of germ cells at different stages of differentiation are now well established in mammals (for review, see Jégou, 1993). In conditions determined to avoid cell competition for limiting molecules of the culture medium or for ${ }^{3} \mathrm{H}$-Tdr, the addition of differentiated $\mathrm{Go}+\mathrm{CI}$ in inserts above $\mathrm{SC}$ layers decreased the proliferative activity of the first generations of $\mathrm{Go}$ included in SC. This suggests that SC-mediated interactions between germ cells probably occur in trout seminiferous tubules. This observation also establishes that the calculation used to determine ${ }^{3} \mathrm{H}$ - $\mathrm{Tdr}$ incorporation by $\mathrm{Go}+\mathrm{CI}$ added onto $\mathrm{SC}$ layers, provides underestimated values, since the incorporation by the Go included in the SC was in fact lower in the co-cultures than in the SC layer cultures. This fact precludes 
us from knowing whether co-culture in contact and in the bicameral system induced the same inhibition on the proliferative activity of the added Go $+\mathrm{CI}$ or not. However, the comparison of the effect of the 2 co-culture systems on the total amount of ${ }^{3} \mathrm{H}$-Tdr incorporated by both mitotic germ cell populations put together (Fig. 7), indicated that the inhibition was higher when the 2 populations were in contact than when they were separated. So, our data show that during the spermatogenetic phase the SC exert an inhibiting control on the mitotic germ cells via diffusible and plasma membrane molecules. It is now well established that in mammals these two mechanisms are involved in SCgerm cell interactions (for review, see Jégou, 1993).

Although the effect of SC at the end of a reproductive cycle on spermatogonial multiplication was investigated only by cultures in SCCM, our data suggest that such SC either acquire the ability to stimulate spermatogonial divisions, or lose the ability to inhibit them. The ability for the SC to have opposite in vitro effects on germ cell proliferation, according to the maturation stage, has been already reported with co-cultures of gonocytes and SC from immature and neonatal rat testes (Dissel-Emiliani, 1991). In the trout, as in the rat, the active factors secreted by the SC in a maturation stage dependent manner are unknown.

The presence of either SC or SCCM consistently reduced the response of $\mathrm{Go}+\mathrm{CI}$ to IGF-I, whatever the maturation stage of the testes was. However, the decrease in sensitivity to IGF-I $\left(E_{50}^{-1}\right)$ and the inhibition of IGF-I stimulation were higher when SC were present than when SCCM was used. In fact, this difference is likely due to some sequestration (non specific binding) of a part of IGF-I by the SC and proportional to the cell number. Cultures in SCCM are not concerned by this artifact and they have demonstrated that $\mathrm{SC}$ always act as moderators of the response of mitotic germ cells to IGF-I.

No effect of s-GtH-II mediated via the SC has been observed. According to Schulz et al. (1988), trout SC are not GtH-II-immunoreactive. These data suggest that the target testicular cells would be Leydig cells rather than the SC. According to Pickford et al. (1972), bovine GH should be able to stimulate spermatogonial proliferation in hypophysectomised killifish. Although GH receptors are present in the trout testis (Le Gac et al., 1992), the potential testicular target cells are unknown. No in vitro SC-mediated effect of GH was observed with spermatogenetic SC. Conversely, GH has induced a decrease of the basal proliferative activity of spermatogenetic Go $+\mathrm{CI}$ in 2 out of 3 experiments carried out with SC (SCCM) from testes at the end of a cycle. At this time, the plasma levels of $\mathrm{GH}$, which were high during spermiation, decrease rapidly (Le Gac et al., 1992). If the moderating role of $\mathrm{GH}$ during spermiation and regression phases is confirmed, this would point out that SC (stimulatory activity) and at least GH (inhibitory activity) interact during this period to maintain the Go in a quiescent state, then to trigger the onset of a new spermatogenesis.

In conclusion, our first results indicate that proliferation of the trout mitotic germ cells is directly influenced by IGF-I, while it is not by the other tested hormones. We have observed that in vitro, according to their maturation stage, the SC either depress or stimulate the basal proliferative activity of Go and CI. However, it is not known whether the activity displayed by Go $+\mathrm{CI}$ removed from the cystic environment is representative of the autonomous intrinsic activity they have in situ, or if it results of the persistence of diverse extrinsic regulating mechanisms. So, the control exerted effectively, in situ, by the SC could be somewhat different. Further investigations are needed, especially to identify the active factors secreted by the SC and the endocrine and/or paracrine regulation of their production.

\section{Acknowledgements}

This work was supported by grants from the Ministère de la Recherche et de la Technologie (no. 91 $T$ 0440) and from the Institut de la Recherche Agronomique (AIP Interactions intragonadiques). We thank Drs. P.Y. Le Bail and F. Le Gac for helpful discussions and Dr. B. Jégou for critical reading of the manuscript. We are grateful to Mrs C. Cauty for her skilful assistance in the preparation of sections for E.M., Mr J.Y. Lefeuvre for excellent assistance in preparing the figures and Mrs J. Hall for help with the English.

\section{References}

Bartlett, J.M.S., Weinbauer, G.F. and Nieschlag, E. (1989) J. Endocrinol. 121, 49-58.

Billard, R. (1983) Cell Tissue Res. 230, 495-502.

Billard, R. and Escaffre, A.M. (1975) Bull. Fr. Pisci. 256, 111-113.

Callard, G.C., Mak, P., Dubois, W. and Cuevas, M.E. (1989) J. Exp. Zool. 2, 23-34.

Chemes, H.E., Dym, M. and Raj, H.G.M. (1979) Biol. Reprod. 21, 241-249.

Cochran, R.C. (1992) J. Exp. Zool. 261, 143-150.

Czernin, S., Gessl, A., Wilfing, A., Trieb, K., Waldhäusl, W., Vierhapper, H., Förster, O. and Grubeck-Loebenstein, B. (1993) Int. Arch. Allergy Immunol. 101, 240-246.

Dissel-Emiliani van, F.M.F. (1991) PhD thesis.

Dombrowicz, D., Hooghe-Peters, E.L., Gothot, A., Vanhaelst, L., Closset, L. and Hennen, G. (1992) Arch. Int. Physiol. Biochim. Biophys.100, 303-308.

Dubois, W. and Callard, G.V. (1993) J. Exp. Zool. 267, 233-244.

Giordano, G., Del Monte, P. and Minuto, F. (1991) J. Endocrinol. Invest. 15, 67-75. 
Hakovirta, H., Kaipia, A., Söder, O. and Parvinen, M. (1993) Endocrinology 133, 1664-1668.

Hansson, H.A., Billig, H. and Isgaard, J. (1989) Biol. Reprod. 40, 1321-1328.

Jégou, B. (1993) Int. Rev. Cytol. 147, 25-96.

Johnson, O.W., Utter, F.M. and Rabinovitch, P.S. (1987) Copeia 4, 1001-1009.

Khan, I.A., Lopez, E. and Leloup-Hatey, J. (1987) GeIl. Comp. Endocrinol. 68, 91-103.

Le Gac, F., Ollitrault, M., Loir, M. and Le Bail, P.Y. (1992) Biol. Reprod. 46, 949-957.

Le Gac, F. and Loir, M. (1993) Reprod. Nutr. Dev. 33, 80.

Loir, M. (1988) Gamete Res. 20, 437-458.

Loir, M. (1989) Gamete Res. 24, 151-169.

Loir, M. (1990) Cell Tissue Res. 261, 133-144.

Loir, M. and Sourdaine, P. (1994) in Biochemistry and Molecular Biology of Fishes: Analytical Techniques (Hochachka, P.W. and Mommsen, T.P., eds.), Elsevier, New York, in press.

Magri, M.H., Solari, A., Billard, R. and Reynaud, P. (1985) Gen. Comp. Endocrinol. 57, 411-421.

Mather, J.P., Attie, K.M., Woodruff, T.K., Rice, G.C. and Phillips, D.M. (1990) Endocrinology 127, 3206-3214.
Neufeld, G. and Gospodarowicz, D. (1987) J. Cell. Physiol. 132, 287-294.

Pickford, G.E., Lofts, B., Bara, G. and Atz, J.W. (1972) Biol. Reprod. 7, 370-386.

Remacle, C. (1976) Gen. Comp. Endocrinol. 29, 480-491.

Ruby, S.M., Jarolawski, P. and Hull, R. (1993) Aquat. Toxicol. 26, 225-238.

Schulz, R., Goos, H.J.T. and Blüm, V. (1988) Cell Tissue Res. 251, 665-669.

Smith, E.P., Dickson, B.A. and Chernausek, S.D. (1990) Endocrinology 127, 2744-2751.

Söder, O., Bang, P., Wahab, A. and Parvinen, M. (1992) Endocrinology 131, 2344-2350.

Sundararaj, B.I.,Nayyar, S.K, Anand, T.C. and Donaldson, E.M. (1971) Gen. Comp. Endocrinol. 17, 73-82.

Swanson, P., Bernard, M., Nozaki, M., Suzuki, K., Kawauchi, H. and Dickhoff, W.W. (1989) Fish Physiol. Biochem. 7, 169-176.

Tres, L.L., Smith, E.P., Van Wyk, J.J. and Kierszenbaum, A.L. (1986) Exp. Cell Res. 162, 33-50.

Upadhyay, S.N. (1977) University of Paris, Dr. Sc. Thesis.

Vizziano, D. (1993) University of Rennes, Dr. Sc. Thesis. 